\title{
Soil Quality at Rice Fields with Organic, Semi-organic and Inorganic Management in Wonogiri Regency, Indonesia
}

\author{
Supriyadi*, Intan Lestari Prima Vera and Purwanto \\ Department of Soil Science, Faculty of Agriculture, Universitas Sebelas Maret, Surakarta, Indonesia \\ *Corresponding author: supriyadi_uns@staff.uns.ac.id
}

\begin{abstract}
The high demand of rice is fulfilled by intensification, particularly with the use of chemical fertilizer that allegedly causes land and environmental problems in a long term. As public awareness of environmental health rises, more rice fields are managed organically and semi-organically, but there are still many that manage rice fields inorganically. Assessment of soil quality of the three types of rice field management is important to prove that organic rice fields have better soil quality than semi-organic and inorganic rice fields, as well as to evaluate soil conditions on the location. This research was conducted in Girimarto, Wonogiri, Indonesia, using a descriptive explorative method with a survey approach on three points of each management system of rice fields, which are organic, semi-organic and inorganic rice fields. Statistical analysis was performed by Pearson correlation analysis and principal component analysis (PCA) to determine the indicators affecting soil quality, which are called the minimum data set (MDS). There were selected indicators in this research, including total microbes, base saturation, cation exchangeable capacity and organic carbon. Based on the results of the study, organic rice fields have the best soil quality with a score of soil quality index (SQI) of 2.3, compared to semi-organic rice field SQI (2.2) and inorganic rice field SQI (1.7). The results indicate that organic management contributes to better soil quality and environment.
\end{abstract}

Keywords: organic management; principal component analysis; rice fields; soil quality; SQI

Cite this as: Supriyadi, Vera, I. L. P., \& Purwanto. (2021). Soil Quality at Rice Fields with Organic, Semiorganic and Inorganic Management in Wonogiri Regency, Indonesia. Caraka Tani: Journal of Sustainable Agriculture, 36(2), 259-269. doi: http://dx.doi.org/10.20961/carakatani.v36i2.42556

\section{INTRODUCTION}

Rice is the main staple food for the people in Indonesia. The need of rice is increasing every year, encouraging farmers to make an effort to increase rice production by intensification. Intensification is implemented by using chemical fertilizers in the fields but prolonged use of fertilizers has caused environmental problems (Supriyadi et al., 2017). Increased agricultural, fishery and livestock activities to meet the needs of life contaminate water, air and soil (Haryuni et al., 2020). Supriyadi et al. (2017) stated that continuous use of rice fields can cause a decrease in soil fertility and quality (land degradation). Moreover, massive continuous use of inorganic fertilizers has a negative impact on the environment and productivity of agricultural land (Supartha et al., 2012). The use of excessive chemical fertilizers can decrease soil quality in the future (Dewanto et al., 2013). The increasing intensity of fertilizer use has made agricultural intensification have a negative impact on the ecosystem. The use of chemical fertilizers always has an impact on biological fertility and the physical condition of the soil. In comparison with chemical based intensive inorganic farming, organic farming have advantageous effects on

\footnotetext{
* Received for publication July 1, 2020

Accepted after corrections April 19, 2021
} 
the various aspects of environment, such as soil, water and biodiversity, as well as human health (Maharjan et al., 2017).

Soil quality is defined as the capacity of particular types of soil to function, within the boundaries of ecosystems that are maintained or managed naturally, to support animal plants and products, keep or improve water and air quality, and support human health and shelter (Cherubin et al., 2016). Soil quality and environmental health can decrease due to the continuous use of inorganic fertilizers or chemical fertilizers. Inorganic fertilizers that are given to the soil in the long term can affect the physical and chemical properties of the soil, such as damage to soil structure, decreased levels of organic matter in the soil and environmental pollution (Isnaini, 2005).

Organic farming systems are one way to overcome land degradation and improve soil quality. An organically management of rice fields contributes to better soil quality than inorganic ones (Supriyadi et al., 2018). Girimarto Sub-district in Wonogiri Regency, Central Java Province of Indonesia, is one of the areas having an organic farming system in rice fields to produce rice. Assessment and comparison of soil quality in organic, semi-organic and inorganic rice fields are important to identify and prove that organic land management contributes to the soil quality.

Most soils in Indonesia generally have low C-organic content due to high temperatures and low decomposition rates, as well as low organic matter returns. These problems can be overcome by implementing an organic rice system, one of which is by utilizing organic fertilizer (Mujiyo et al., 2015). Organic farming contributes to environment healthier because it reduces the use of synthetic chemicals. Organic materials used for agriculture with organic processing are obtained from agricultural residues. The organic materials can come from agricultural waste, green manure, weeds and livestock manure (Anshori et al., 2016).

Decreasing levels of soil organic matters can be due to excessive tillage, which is not kept in balance by organic fertilizer application. Organic matter content is also influenced by aerobic/anaerobic atmosphere in the land. Mineralization of organic matter is easier to occur on dry rice fields with an aerobic atmosphere compared to rice fields with anaerobic atmosphere. Clay content also affects the soil organic matter content. Soils with high clay content mostly contain higher organic matter compared to soils with low clay content (Tangketasik et al., 2014)

Soil management with conventional, organic and low input systems increases soil microbial biomass by the presence of high organic material inputs in conventional farming system and low inputs (Prihastuti, 2011). Rice planted with organic farming system is proven to produce higher yields than rice planted with inorganic (conventional) farming system. This can be seen when physiologically mature rice and organic rice remain having more green yellow seeds $(17.6 \%)$ than rice planted with inorganic processing systems (15.2\%) (Priadi et al., 2017). Thus, it can be said that organic farming can create a healthy environment (Anshori et al., 2016). Organic farming uses natural resources to improve land productivity and avoid the use of chemicals. This type of farming can increase productivity and soil health.

The addition of organic matter can improve the quality of soil properties. If soil organic matter decreases, it can cause an increase in soil weight and a decrease in soil porosity. Organic matter can change the biological properties of soil by intensifying soil microbial populations. Increased microbial population causes soil dynamics to improve and become naturally healthy. The ability to change the biological properties of the soil in a positive direction can increase microbial populations that benefit plants and make plants grow healthy (Prihastuti, 2011). The soil degradation potency in Girimarto is low, which is generally related to soil quality (Mujiyo et al., 2016).

This research is to assess the soil quality related to the three types of rice fields management essential to prove that organic rice fields have better soil quality than semiorganic and inorganic rice fields, as well as to evaluate soil condition in the areas. Periodic soil quality assessment is required to show the capacity of soil to function effectively at present and in the future or as the capacity of a soil to function within ecosystem boundaries to sustain biological productivity, maintain environmental quality and promote plant and animal health, such as the criteria for sustainable agriculture presented by the FAO. These criteria are meeting present and future needs of food, 
providing jobs in agriculture, maintaining and increasing the productivity of natural resources and making the agricultural sector more resilient (Chen, 1999).

\section{MATERIALS AND METHOD}

\section{Fields survey}

This research was carried out in Girimarto Sub-district, Wonogiri Regency, Central Java Province of Indonesia, from September to November 2018. The research location is situated at $7^{\circ} 46^{\prime} 11.90^{\prime \prime}$ South Latitude and $111^{\circ} 4{ }^{\prime} 54.51^{\prime \prime}$ East Longitude. The soil ordo is Inceptisol. Based on climate type according to Schmidt Ferguson (1961), Girimarto has a type C climate (rather wet). Girimarto Sub-district is geographically positioned at the foot of Mount Lawu, with altitudes ranging from 470-700 masl (meters above sea level). Purposive sampling technique was applied based on the types of land management, including organic, semi-organic and inorganic management (Figure 1).

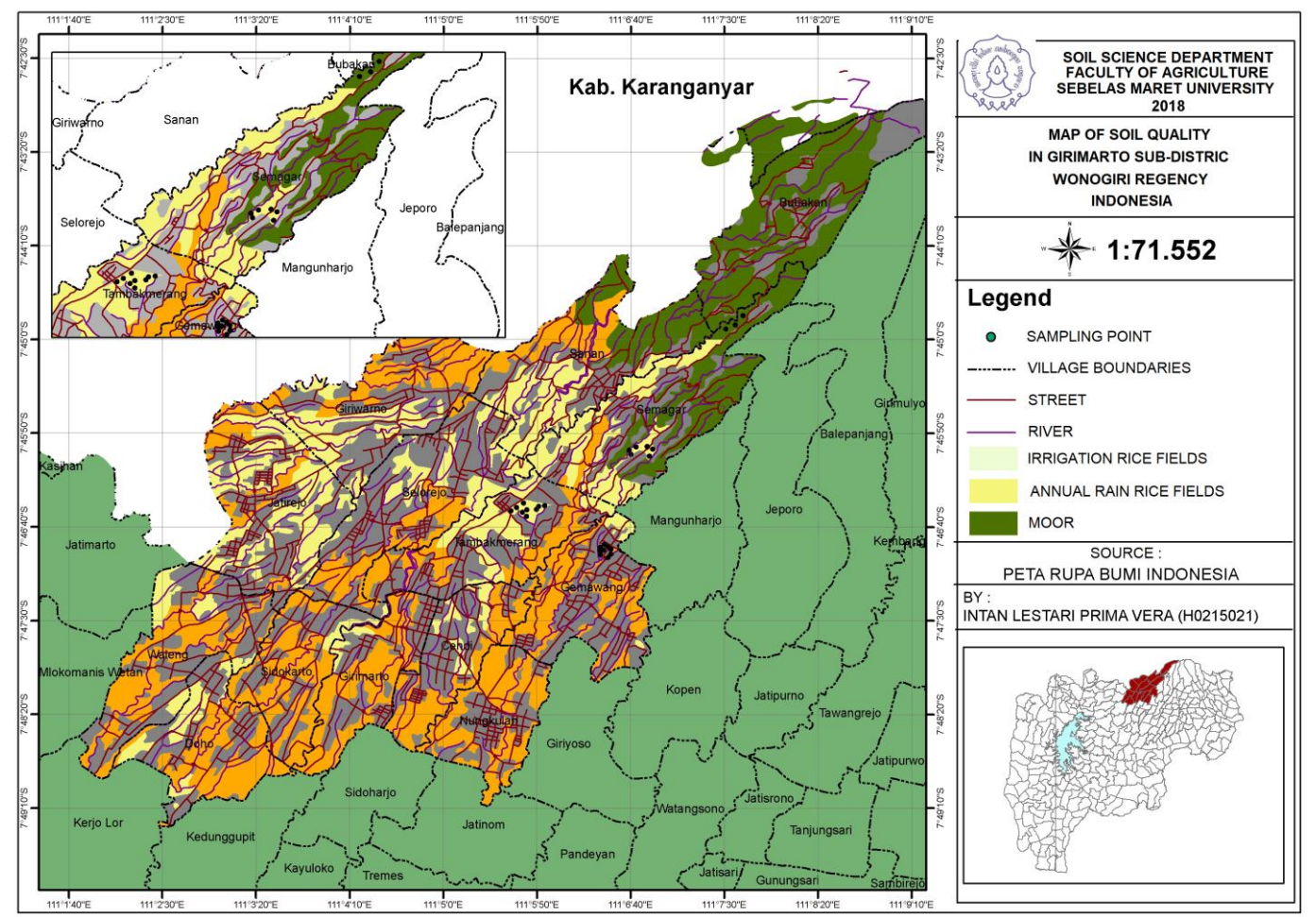

Figure 1. Map of soil quality in Girimarto Sub-district, Wonogiri, Indonesia

Sampling location was based on the overlay among the land map of the soil type, the map of the administration, the map of the distribution of host rock and the map of land use. Soil samples at each research point were taken in a composite manner (Supriyadi et al., 2015), both soil samples for observation of soil biological properties, soil chemistry and soil physics. Samples were obtained at a depth of 0-20 $\mathrm{cm}$ from the ground. In each type of rice field, samples were taken at three points with three replications to represent soil conditions in the area.

\section{Laboratory analysis}

Analysis of soil physical, chemical and biological properties were carried out at the Laboratory of the Faculty of Agriculture,
Universitas Sebelas Maret, Surakarta, Indonesia. The analysis of those properties is presented in Table 1.

\section{Data analysis}

The results of the laboratory analysis of soil quality indicators were examined using Minitab software 18. Correlation of soil quality indicators was studied using the Pearson correlation analysis and then continued with the principle component analysis (PCA) to determine the indicators selected as the minimum data sets (MDS). Calculation of soil quality was performed by summing the indicator scores that had been multiplied by the weight index. Assessment of soil quality using soil quality index or SQI (Liu et al., 2014) applied the following formula: 


$$
\mathrm{SQI}=\sum_{\mathrm{i}=1}^{\mathrm{n}} \mathrm{Wi} \times \mathrm{Si}
$$

Description:

$\mathrm{Wi}=$ Weighting factor

$\mathrm{Si} \quad=$ The indicator score for variable
After the results of data analysis were obtained, the soil quality index of organic rice fields was compared with the quality index of semi-organic and inorganic rice fields to prove that organically managed rice fields have better soil quality.

Table 1. Soil physical, chemical and biological properties analyzed in this study

\begin{tabular}{|c|c|c|}
\hline Parameter & Analytical method & References \\
\hline Bulk density & Pycnometer & (Soil Research Institute, 2009) \\
\hline $\mathrm{pH}$ & Electrometric & (Soil Research Institute, 2009) \\
\hline Available P & Olsen method & (Soil Research Institute, 2009) \\
\hline Soil organic carbon & Walkey and black & (Soil Research Institute, 2009) \\
\hline Total N & Kjeldahl & (Soil Research Institute, 2009) \\
\hline CEC & Ammonium acetate method & (Soil Research Institute, 2009) \\
\hline Base saturation & Ammonium acetate extraction & (Soil Research Institute, 2009) \\
\hline Exchangeable Al & Potassium chloride extraction & (Soil Research Institute, 2009) \\
\hline $\mathrm{qCO}_{2}$ & Verstraete & $\begin{array}{l}\text { (Center for Research and Development } \\
\text { Agricultural Land Resources, 2007) }\end{array}$ \\
\hline Total microbes & Total plate count & $\begin{array}{l}\text { (Center for Research and Development } \\
\text { Agricultural Land Resources, 2007) }\end{array}$ \\
\hline $\begin{array}{l}\text { Carbon microbial } \\
\text { biomass }\end{array}$ & Fumigation and extraction & $\begin{array}{l}\text { (Center for Research and Development } \\
\text { Agricultural Land Resources, 2007) }\end{array}$ \\
\hline
\end{tabular}

Note: $\mathrm{CEC}=$ cation exchangeable capacity; $\mathrm{qCO}_{2}=$ soil respiration

\section{RESULTS AND DISCUSSION}

Physical, chemical and biological indicators were used to evaluate soil quality. Chemical indicators can give information about the balance between soil solution and exchange sites. Physical indicators provide information about soil hydrologic characteristics, such as water entry and retention that influence availability to plants. Biological indicators inform about the organisms that form the soil food web responsible for the decomposition of organic matter and nutrient cycling (Sparling, 2020). Table 2 demonstrates the results of laboratory analysis on each type of rice field management that supports the assessment of soil quality. The outcomes of this study signify that the parameters of organic rice have a higher value than those of semi-organic and inorganic rice fields, except bulk density, CEC, base saturation, exchangeable $\mathrm{Al}$ and carbon microbial biomass.

Table 2. Average value of each soil quality parameter on three organic rice management systems

\begin{tabular}{lccc}
\hline \multicolumn{1}{c}{ Parameter } & Organic & Semi-organic & inorganic \\
\hline Bulk density $\left(\mathrm{g} \mathrm{cm}^{-3}\right)$ & 2.1 & 2.2 & 2.3 \\
$\mathrm{pH}$ & 6.3 & 6.1 & 6.0 \\
Available $\mathrm{P}(\mathrm{ppm})$ & 14.2 & 11.2 & 10.0 \\
Available K & 27.4 & 21.2 & 15.8 \\
Soil Organic Carbon $(\%)$ & 2.0 & 1.9 & 1.4 \\
Total N $(\%)$ & 0.4 & 0.3 & 0.3 \\
CEC $\left(\mathrm{cmol} \mathrm{kg}^{-1}\right)$ & 13.2 & 13.7 & 12.6 \\
Base Saturation $(\%)$ & 26.8 & 27.0 & 22.8 \\
Exchangeable Al & 2.8 & 2.4 & 3.1 \\
qCO $\left(\mathrm{lbs} \mathrm{CO}_{2}\right.$-C/a/d) & 2.7 & 1.2 & 1.3 \\
Total microbes $(\mathrm{CFU})$ & $3 \times 10^{\wedge} 6$ & $1.8 \times 10^{\wedge} 6$ & $10 \times 10^{\wedge} 5$ \\
$\mathrm{CMB}$ & 27.9 & 30.4 & 10.7 \\
\hline
\end{tabular}

Note: $\mathrm{CEC}=$ cation exchangeable capacity; $\mathrm{qCO}_{2}=$ soil respiration; $\mathrm{CMB}=$ carbon microbial biomass. The presented data are the average values of three replication 
The $\mathrm{pH}$ of organic rice fields is 6.3 , whereas the $\mathrm{pH}$ in semi-organic rice fields and inorganic 6.0 are 6.1 and 6.0, respectively. Organic rice fields have a more neutral $\mathrm{pH}$. Organic rice has a higher $\mathrm{pH}$ and this value is close to neutral because of the addition of organic matter. Cyio (2008) states that an increase in $\mathrm{pH}$ value is due to the contribution of organic matter, which releases $\mathrm{OH}$ ions because of the reduction process.

Table 2 displays that available $\mathrm{P}$ on organic rice fields is higher $(14.2 \mathrm{ppm})$ than that in the semi-organic rice fields (11.2 ppm) and inorganic rice fields $(10 \mathrm{ppm})$. The available $\mathrm{K}$ in organic rice fields is also higher (27.4 $\mathrm{ppm})$ than that in semi-organic rice fields $(21.2$ $\mathrm{ppm})$ and inorganic rice fields (15.8 ppm). These conditions are due to the addition of organic matter. This is consistent with the finding of previous research that the addition of organic matter can increase available P soil (Irawan et al., 2016). An increase in available $P$ may be attributed to the decomposition process that produces humus which helps release $\mathrm{P}$ bound by an amorphous fraction so that the available $\mathrm{P}$ concentration increases. Nevertheless, extensive continuous rice cultivation without the use of potassium and phosphorus fertilizers reduces the available $\mathrm{K}$ and available $\mathrm{P}$ concentrations in the studied rice fields soils (Rezaee et al., 2020).

Organic rice fields have the highest soil organic carbon among three types of rice fields. The soil organic carbon contents in organic, semi-organic and inorganic rice fields are $2.0 \%, 1.9 \%$ and $1.4 \%$, respectively. The soil organic carbon is low when compared to rice fields, where the majority have relatively high soil organic carbon ranging from $4.17 \%$ to $47.92 \%$ (Tangketasik et al., 2014). Accelerated mineralization of SOC is good for soil fertility (Ma et al., 2017). Low organic carbon may because it is used by microorganisms to carry out their activities. This corresponds to the results of analysis on the total microbes. Total microbes in organic rice fields are the highest $\left(3 \times 10^{\wedge} 6\right.$ $\mathrm{CFU}$ ), compared to the total microbes of other types of rice fields, the semi-organic rice fields $\left(1.8 \times 10^{\wedge} 6 \mathrm{CFU}\right)$ and inorganic rice fields $\left(10 \times 10^{\wedge} 5 \mathrm{CFU}\right)$. According to Das et al. (2016), after 18 years of intensive cropping, NPK fertilizer and organic matter application significantly influence soil organic carbon. The increased plant biomass with balanced fertilizer application results in higher SOC.

Organic rice fields also have higher Total $\mathrm{N}$ than semi-organic and inorganic rice fields. Total $\mathrm{N}$ in organic rice fields is $0.4 \%$, while the total $\mathrm{N}$ in both semi-organic and inorganic is $0.3 \%$. Inorganic rice fields use inorganic fertilizers with higher $\mathrm{N}$ concentrations, but $\mathrm{N}$ contained in inorganic fertilizers have the disadvantages of evaporating faster, while organic and semi-organic rice fields are overgrown with Azolla pinnata. A. pinnata is known to be associated with Anabaena azollae which can fix nitrogen so that nitrogen content in organic and semi-organic rice fields is higher than in inorganic rice fields. Semiorganic rice fields have the highest CEC and base saturation. This may because this type of rice field benefits a combination of organic and inorganic fertilizers. CEC in organic rice fields is $13.2 \mathrm{cmol} \mathrm{kg}^{-1}$, while in semi-organic is $13.7 \mathrm{cmol} \mathrm{kg}^{-1}$ and inorganic is $12.6 \mathrm{cmol}$ $\mathrm{kg}^{-1}$. Base saturation in semi-organic rice fields is $27 \%$, while the base saturation in the organic and inorganic rice fields are $26.8 \%$ and $22.8 \%$, respectively. Nitrogen and organic matter are interrelated. The carbon-nitrogen $(\mathrm{C} / \mathrm{N})$ ratio shows an overview of the nitrogen content in the soil, which can be an indication of the use of available nitrogen in the soil (Patti et al., 2018).

Soil respiration of organic rice fields is the highest among the other types of rice fields, which is presumably because organic rice fields only use organic matter inputs so they have better environmental conditions suitable for microbes to live. The three types of rice fields have different soil respiration, organic rice fields $\left(2.7 \mathrm{lbs} \quad \mathrm{CO}_{2}-\mathrm{C} / \mathrm{a} / \mathrm{d}\right)$, semi-organic rice fields $\left(1.2 \mathrm{lbs} \mathrm{CO}_{2}-\mathrm{C} / \mathrm{a} / \mathrm{d}\right)$ and inorganic rice fields $\left(1.3 \mathrm{lbs} \mathrm{CO}_{2}-\mathrm{C} / \mathrm{a} / \mathrm{d}\right)$. The highest carbon microbial biomass (CMB) is in semi-organic rice fields. Soil with high $\mathrm{CMB}$ content will cause decomposition, nutrient cycle and decomposition of other organic and inorganic compounds (Susilawati et al., 2013). Semiorganic rice fields have the highest CMB (30.4), followed by organic rice fields (27.9) and inorganic rice fields (10.7).

In this study, it is necessary to identify the indicators that are mutually correlated and 
influential. The relation of the properties can be determined through correlation analysis
(Supriyadi et al., 2018). The results of the correlation analysis are presented in Table 3.

Table 3. The results of correlation analysis of each soil quality parameter on three organic rice management systems

\begin{tabular}{|c|c|c|c|c|c|c|c|c|c|c|c|}
\hline & $\mathrm{qCO}_{2}$ & $\begin{array}{c}\text { Total } \\
\text { microbes }\end{array}$ & $\mathrm{CMB}$ & $\begin{array}{c}\text { Total } \\
\mathrm{N}\end{array}$ & $\begin{array}{c}\text { Av. } \\
P\end{array}$ & $\begin{array}{c}\text { Org. } \\
\mathrm{C}\end{array}$ & $\mathrm{pH}$ & CEC & $\mathrm{BS}$ & $\begin{array}{c}\text { Av. } \\
\mathrm{K}\end{array}$ & $\begin{array}{c}\text { Bulk } \\
\text { density }\end{array}$ \\
\hline Total microbes & $\begin{array}{l}0.8 \\
0.02\end{array}$ & & & & & & & & & & \\
\hline CMB & $\begin{array}{l}0.7 \\
0.1\end{array}$ & $\begin{array}{l}0.9 \\
0.0\end{array}$ & & & & & & & & & \\
\hline Total N & $\begin{array}{l}0.5 \\
0.2\end{array}$ & $\begin{array}{l}0.6 \\
0.1\end{array}$ & $\begin{array}{l}0.5 \\
0.1\end{array}$ & & & & & & & & \\
\hline Available P & $\begin{array}{l}0.6 \\
0.1\end{array}$ & $\begin{array}{l}0.8 \\
0.0\end{array}$ & $\begin{array}{l}0.8 \\
0.0\end{array}$ & $\begin{array}{l}0.8 \\
0.0\end{array}$ & & & & & & & \\
\hline Organic carbon & $\begin{array}{l}0.5 \\
0.1\end{array}$ & $\begin{array}{l}0.9 \\
0.0\end{array}$ & $\begin{array}{l}0.9 \\
0.0\end{array}$ & $\begin{array}{l}0.4 \\
0.3\end{array}$ & $\begin{array}{l}0.7 \\
0.0\end{array}$ & & & & & & \\
\hline $\mathrm{pH}$ & $\begin{array}{l}0.6 \\
0.1\end{array}$ & $\begin{array}{l}0.9 \\
0.0\end{array}$ & $\begin{array}{l}0.8 \\
0.0\end{array}$ & $\begin{array}{l}0.6 \\
0.1\end{array}$ & $\begin{array}{l}0.7 \\
0.0\end{array}$ & $\begin{array}{l}0.9 \\
0.0\end{array}$ & & & & & \\
\hline CEC & $\begin{array}{r}-0.3 \\
0.5\end{array}$ & $\begin{array}{l}0.2 \\
0.6\end{array}$ & $\begin{array}{l}0.3 \\
0.4\end{array}$ & $\begin{array}{l}0.5 \\
0.1\end{array}$ & $\begin{array}{l}0.4 \\
0.3\end{array}$ & $\begin{array}{l}0.3 \\
0.4\end{array}$ & $\begin{array}{l}0.4 \\
0.4\end{array}$ & & & & \\
\hline Base saturation & $\begin{array}{l}0.1 \\
0.8\end{array}$ & $\begin{array}{l}0.1 \\
0.8\end{array}$ & $\begin{array}{l}0.2 \\
0.7\end{array}$ & $\begin{array}{r}-0.4 \\
0.3 \\
\end{array}$ & $\begin{array}{r}-0.3 \\
0.5 \\
\end{array}$ & $\begin{array}{l}0.3 \\
0.5\end{array}$ & $\begin{array}{l}0.3 \\
0.4\end{array}$ & $\begin{array}{r}-0.2 \\
0.5 \\
\end{array}$ & & & \\
\hline Available K & $\begin{array}{l}0.7 \\
0.1\end{array}$ & $\begin{array}{l}0.7 \\
0.0\end{array}$ & $\begin{array}{l}0.7 \\
0.0\end{array}$ & $\begin{array}{l}0.6 \\
0.1\end{array}$ & $\begin{array}{l}0.5 \\
0.2\end{array}$ & $\begin{array}{l}0.7 \\
0.0\end{array}$ & $\begin{array}{l}0.9 \\
0.0\end{array}$ & $\begin{array}{l}0.2 \\
0.6\end{array}$ & $\begin{array}{l}0.5 \\
0.2\end{array}$ & & \\
\hline Bulk density & $\begin{array}{r}-0.3 \\
0.5\end{array}$ & $\begin{array}{r}-0.5 \\
0.2\end{array}$ & $\begin{array}{r}-0.5 \\
0.1\end{array}$ & $\begin{array}{r}-0.6 \\
0.1\end{array}$ & $\begin{array}{r}-0.4 \\
0.3\end{array}$ & $\begin{array}{r}-0.4 \\
0.3\end{array}$ & $\begin{array}{r}-0.7 \\
0.0\end{array}$ & $\begin{array}{r}-0.6 \\
0.1\end{array}$ & $\begin{array}{r}-0.3 \\
0.4\end{array}$ & $\begin{array}{r}-0.7 \\
0.1\end{array}$ & \\
\hline $\mathrm{Al}$ & $\begin{array}{l}0.1 \\
0.9\end{array}$ & $\begin{array}{r}-0.2 \\
0.7\end{array}$ & $\begin{array}{r}-0.4 \\
0.2\end{array}$ & $\begin{array}{r}-0.0 \\
0.9\end{array}$ & $\begin{array}{r}-0.4 \\
0.3\end{array}$ & $\begin{array}{r}-0.4 \\
0.4\end{array}$ & $\begin{array}{l}0.0 \\
0.9\end{array}$ & $\begin{array}{r}-0.4 \\
0.3\end{array}$ & $\begin{array}{l}0.0 \\
0.8\end{array}$ & $\begin{array}{l}0.0 \\
0.9\end{array}$ & $\begin{array}{r}-0.1 \\
0.8\end{array}$ \\
\hline
\end{tabular}

Note: $\mathrm{qCO}_{2}=$ soil respiration; $\mathrm{CMB}=$ carbon microbial biomass; Av. $\mathrm{P}=$ available $\mathrm{P} ;$ Org. $\mathrm{C}=$ organic carbon; $\mathrm{CEC}=$ cation exchangeable capacity; $\mathrm{BS}=$ base saturation; Av. $\mathrm{K}=$ available $\mathrm{K}$

Pearson correlation analysis in this study used level 5\% ( $\alpha=0.05)$, where two indicators are considered having a strong correlation if the Pearson correlation value (r) is approaching 1 or -1 or P-value is less than 0.05 (Azis, 2015). The results of the correlation analysis show positive and negative correlations. Almost all indicators that strongly linking have a positive correlation, except bulk density. A positive correlation means if one of the interrelated indicators increases, the other indicators will also increase. Otherwise, negative correlation means if one indicator increases, the other correlated indicators will decrease.

Positive correlation is indicated by the relation of total microbes with $\mathrm{qCO}_{2}(\mathrm{r}=0.8), \mathrm{CMB}$ $(\mathrm{r}=0.9)$, available $\mathrm{P}(\mathrm{r}=0.8)$, organic carbon $(\mathrm{r}=0.9), \mathrm{pH}(\mathrm{r}=0.9)$ and available $\mathrm{K}(\mathrm{r}=0.7)$. Soil respiration is a process that occurs because of the activity of microbes in the soil.
The determination of soil respiration is based on the amount of $\mathrm{CO}_{2}$ produced by soil microbes and the amount of $\mathrm{O}_{2}$ used by soil microbes. If the number of microbes in the soil rises, soil respiration will also multiply (Susilawati et al., 2013). The presence of microbes in the soil can increase carbon microbial biomass in the soil. Good soil will have a sufficient amount of microbes that will perform several roles such as destroying organic waste, plant nutrient cycles, nitrogen fixation and phosphate solvents; stimulating growth; serves as the bio control of pathogens and helping the absorption of nutrients. With the increasing number of microbes in the soil, the value of carbon microbial biomass will also increase and this will improve the value of organic carbon.

The positive indicator is also indicated by the relation of available $\mathrm{P}$ with total $\mathrm{N}(\mathrm{r}=$ $0.8)$, organic carbon $(\mathrm{r}=0.7)$ and $\mathrm{pH}(\mathrm{r}=0.7)$. 
The activity of phosphate solvent microbes highly depends on soil $\mathrm{pH}$. Mineralization rates also increase in line with $\mathrm{pH}$ values suitable for microbial metabolism. Phosphate release will increase in line with increasing $\mathrm{pH}$ values. Changes in $\mathrm{pH}$ play an important role in increasing phosphate solubility (Thomas et al., 1985). Based on these data, the $\mathrm{pH}$ at the study site is neutral and influenced by microbial metabolism. A positive indicator can be found in the relation of $\mathrm{pH}$ and organic carbon $(\mathrm{r}=0.9)$ and $\mathrm{pH}$ with available $\mathrm{K}(\mathrm{r}=0.9)$. Other than that, positive correlation is signified by the relation of carbon microbial biomass and available $\mathrm{P}(\mathrm{r}=0.8)$, organic carbon $(\mathrm{r}=0.9), \mathrm{pH}(\mathrm{r}=0.8)$ and available $\mathrm{K}(\mathrm{r}=0.7)$.

Negative correlation is only indicated by the relation of $\mathrm{pH}$ and bulk density $(\mathrm{r}=-0.7)$. $\mathrm{pH}$ affects the bulk density, the physical properties of the soil influenced by soil texture and soil organic matter. A neutral soil
$\mathrm{pH}$ can make the soil a comfortable place for plants, microbes and soil fauna to live. Soil organic matter is the accumulation of the remnants of plants and animals, which have experienced weathering and re-formation. Soil organic matter has soil density. More soil organic matter content will cause lower soil density. Organic matter can increase $\mathrm{pH}$ value due to the release of $\mathrm{OH}$ ions (Cyio, 2008).

PCA was performed to select indicators called MDS. Selected indicators are gained under PC (Principle Component) that has eigenvalue $\geq 1$, which is up to PC 4 in this study, as presented in Table 4. The selected indicators are the highest rated indicators of each PC, where the values in the table are rounding. The selected indicator in PC1 is the total microbe, while the PC2 selected indicator is base saturation. The selected indicator in PC3 is CEC, while the PC4 selected indicator is organic carbon.

Table 4. The results of PCA of each soil quality parameter on three organic rice management systems

\begin{tabular}{lcccc}
\hline Eigenvalue & 6.6 & 2.0 & 1.4 & 1.3 \\
\hline Proportion & 0.5 & 0.2 & 0.1 & 0.1 \\
\hline Cumulative & 0.5 & 0.7 & 0.8 & 0.9 \\
\hline Variable & $\mathrm{PC} 1$ & $\mathrm{PC} 2$ & $\mathrm{PC} 3$ & PC4 \\
\hline $\mathrm{qCO}_{2}$ & 0.3 & 0.2 & -0.4 & -0.3 \\
Total microbes & 0.4 & 0.0 & -0.2 & 0.0 \\
CMB & 0.4 & 0.0 & -0.2 & 0.2 \\
Total N & 0.3 & -0.3 & 0.1 & -0.4 \\
Available P & 0.3 & -0.3 & -0.2 & -0.1 \\
Org. C & 0.3 & 0.0 & -0.1 & 0.3 \\
pH & 0.4 & 0.2 & 0.1 & 0.0 \\
CEC & 0.2 & -0.5 & 0.5 & 0.2 \\
BS & 0.1 & 0.6 & 0.2 & 0.4 \\
Available K & 0.3 & 0.3 & 0.2 & 0.0 \\
Bulk density & -0.3 & -0.1 & -0.6 & 0.1 \\
Al & -0.1 & 0.4 & 0.3 & -0.6 \\
\hline
\end{tabular}

Note: $\mathrm{qCO}_{2}=$ soil respiration; $\mathrm{CMB}=$ carbon microbial biomass; Org. $\mathrm{C}=$ organic Carbon; $\mathrm{CEC}=$ cation exchangeable capacity; $\mathrm{BS}=$ base saturation

According to Mukhopadhyay et al. (2014), the first step of PCA was dividing proportion by the number of mine soil quality index (MSQI). Then, the MSQI values were normalized to a $0-1$ scale by dividing each weighing factor by the total weighing factors. The total weighing factor in this analysis was 0.9. After that, the number was multiplied by the score of each indicator $(\mathrm{Si})$. Scoring of soil quality index used a linear method, where the assessment was performed by assigning values in the range from 1 to $5(\mathrm{Si})$. The value of 1 showed the lowest range of scoring, which was progressively rose to 5 , indicating the highest value.

Table 5 shows that two properties of the biological indicator in organic rice fields receive a higher score than in the other management systems. These two properties are the total microbes and organic carbon. Total microbes are scored 3 in organic soils and 2 in both semi-organic and inorganic soils. Similar results were also reported by Van Leeuwen et al. 
(2015) that soil organism biomass, especially of bacteria and nematodes, is consistently higher in organic farms than in conventional farms. Organic carbon is scored 3 in organic rice fields, which is better than the score of organic carbon in semi-organic and inorganic rice fields, which is only 2. Soil organic carbon stocks are higher with organic system than with conventional system during the wet and dry seasons, respectively after 5 years of study (Surekha et al., 2013).

Table 5. Soil quality index in each management system

\begin{tabular}{|c|c|c|c|c|c|c|c|c|c|}
\hline \multirow[t]{2}{*}{ Var } & \multirow[t]{2}{*}{ Pro } & \multirow[t]{2}{*}{ Cum } & \multirow[t]{2}{*}{ WI } & Organic & $\begin{array}{l}\text { Semi- } \\
\text { organic }\end{array}$ & Inorganic & $\begin{array}{c}\text { WI x SI } \\
\text { (Organic) }\end{array}$ & $\begin{array}{l}\text { WI x SI } \\
\text { (Semi- } \\
\text { organic) }\end{array}$ & $\begin{array}{c}\text { WI x SI } \\
\text { (Inorganic) }\end{array}$ \\
\hline & & & & \multicolumn{3}{|c|}{ SI } & & & \\
\hline T. micb & 0.5 & 0.9 & 0.5 & 3 & 3 & 2 & 1.5 & 1.5 & 1.0 \\
\hline CEC & 0.2 & 0.9 & 0.1 & 2 & 2 & 2 & 0.2 & 0.2 & 0.2 \\
\hline BS & 0.6 & 0.9 & 0.2 & 2 & 2 & 2 & 0.3 & 0.3 & 0.3 \\
\hline Org C & 0.3 & 0.9 & 0.1 & 3 & 2 & 2 & 0.3 & 0.2 & 0.2 \\
\hline SQI & & & & & & & 2.3 & 2.2 & 1.7 \\
\hline Score & & & & & & & 4 & 4 & 5 \\
\hline Class & & & & & & & Low & Low & Very low \\
\hline
\end{tabular}

Note: $\mathrm{Var}=$ variable/indicator; pro $=$ proportion; cum =cumulaive; $\mathrm{WI}=$ weigh index; $\mathrm{SI}=$ score indicator; $\mathrm{T}$. micb $=$ total microbes; $\mathrm{CEC}=$ cation exchangeable capacity; $\mathrm{BS}=$ base saturation; $\mathrm{Org} \mathrm{C}=$ organic carbon

Modified from Cantú et al. (2007), both organic and semi-organic rice fields belong to class 4 (low), but inorganic rice fields belong to class 5 (very low). Based on the assessment of SQI value, organic rice fields have the highest score (2.3), followed by semi-organic rice fields (2.2) and inorganic rice fields (1.7) as exhibited in Table 6. Similar results have been revealed by Kalu et al. (2015), that the protected forest in its natural condition has the highest SQI, whereas tilling and the application of fertilizers in the cultivated land decrease the SQI. Also, paddy soil managed organically has better soil quality compared to soil with semi-organic and inorganic management systems (Supriyadi et al., 2019). The agricultural land use and improper management practices have led to degradation of soil quality (Ghaemi et al., 2014). The results depict that all of rice fields have low and very low SQI values, where the organic rice fields has a low soil quality and inorganic rice fields has a very low soil quality (Haryuni et al., 2020; Rezaee et al., 2020).

Table 6. Soil quality classes (modified from Cantu, 2007)

\begin{tabular}{lcc}
\hline \multicolumn{1}{c}{ Soil quality } & Scale & Classes \\
\hline Very good & $0.8-1.00$ & 1 \\
Good & $0.6-0.79$ & 2 \\
Moderate & $0.4-0.59$ & 3 \\
Low & $0.2-0.39$ & 4 \\
Very low & $0.0-1.99$ & 5 \\
\hline
\end{tabular}

These findings indicate that organic management system is better than inorganic management system. The cultivation of rice field has a negative impact on soil quality, decreasing from high to moderate (Sione et al., 2017). Even though organic and semi-organic management systems are on the same class, the SQI value of organic rice fields remains better than the SQI value of semi-organic rice fields. The organic farms differ from the conventional farms for only organic fertilizers are applied and no pesticides are used (Van Leeuwen et al., 2015). Giving different fertilizers will indirectly contribute to different soil properties. One of them is that organic soil has a higher biological activity than inorganic soil because of organic fertilizers. Indirectly, it will affect the availability of nutrients or the physical properties of the soil. The value of SQI is not significantly affected by tillage (Nakajima et al., 2015). Thus, long-term studies are needed be conducted to assess the effects of tillage on SQI.

\section{CONCLUSIONS}

Principle indicators for soil quality assessment are total microbes, CEC, base saturation (BS) and organic carbon. Soil quality in organic and semi-organic rice fields is included in a low class, while the soil quality in inorganic rice fields is included in the very low class. SQI value 
of organic rice fields is the highest among the others (2.3). These indicate that organic management can bring alteration to the better soil quality though it takes a long time.

\section{ACKNOWLEDGEMENT}

This research was supported by Directorate of Research and Community Service, Directorate General of Research and Development Strengthening Ministry of Research, Technology and Higher Education in accordance with Research Contract No: 098/SP2H/DRPM/IV/2017 3 April 2017.

\section{REFERENCES}

Anshori, A., Sunarminto, B. H., \& Haryono, E. (2016). Aliran bahan organik pada sawah padi organik di Dusun Jayan Desa Kebonagung Kec. Imogiri Kab. Bantul D.I. Yogyakarta. Caraka Tani: Journal of Sustainable Agriculture, 31(1), 45-50. https://doi.org/10.20961/carakatani.v31i1.119 42

Azis, A. (2015). Belajar statistik dengan SPSS dan manual. In Lingkaran Matematika. https://doi.org/10.31219/osf.io/pxstu

Cantú, M. P., Becker, A., Bedano, J. C., \& Schiavo, H. F. (2007). Evaluación de la calidad de suelos mediante el uso de inidicadores e índices. Ciencia Del Suelo, 25(2), 173-178. Retrieved from https:// www.researchgate.net/publication/237215276 _Evaluacion_de_la_calidad_de_suelos_media nte_el_uso_de_indicadores_e_indices

Center for Research and Development Agricultural Land Resources. (2007). Soil Biological Analysis Methods (R. Saraswati, E. Husen, \& R. D. M. Simanungkalit, Eds.). Bogor, Jawa Barat: Center for Research and Development of Agricultural Land Resources.

Chen, Z. S. (1999). Selecting indicators to evaluate soil quality. Taipen, Taiwan: Food and Fertilizer Technology Center, 1-20. Retrieved from https://www.fftc.org.tw/htm larea_file/library/20110808172707/eb473.pdf

Cherubin, M. R., Karlen, D. L., Cerri, C. E. P., Franco, A. L. C., Tormena, C. A., Davies, C. A., \& Cerri, C. C. (2016). Soil quality indexing strategies for evaluating sugarcane expansion in Brazil. PLoS ONE, 11(3), 1-26. https://doi.org/10.1371/journal.pone.0150860

Cyio, M. B. (2008). The effectivity of organic matter and water depth on soil Eh and $\mathrm{pH}$ changes and soluble $\mathrm{Fe}, \mathrm{P}$ and $\mathrm{Al}$ status in ultisol. J. Agroland, 15(4), 257-263. Retrieved from https://core.ac.uk/download/pdf/296928 477.pdf

Das, B., Chakraborty, D., Singh, V. K., Ahmed, M., Singh, A. K., \& Barman, A. (2016). Evaluating fertilization effects on soil physical properties using a soil quality index in an intensive rice-wheat cropping system. Pedosphere, 26(6), 887-894. https://doi.org /10.1016/S1002-0160(15)60093-5

Dewanto, F. G., Londok, J. J. M. R., Tuturoong, R. A. V, \& Kaunang, W. B. (2013). Pengaruh pemupukan anorganik dan organik terhadap produksi tanaman jagung sebagai sumber pakan. Zootek Journal, 32(5), 158-171. https://doi.org/10.35792/zot.32.5.2013.982

Ghaemi, M., Astaraei, A. R., Emami, H., Nassiri Mahalati, M., \& Sanaeinejad, S. H. (2014). Determining soil indicators for soil sustainability assessment using principal component analysis of Astan Quds- east of Mashhad- Iran. Journal of Soil Science and Plant Nutrition, 14(4), 987-1004. https:// doi.org/10.4067/s0718-95162014005000077

Haryuni, Wirawati, H., Minardi, S., \& Supriyadi. (2020). Assessment of soil quality in organic and non-organic paddy fields with technical irrigation system in susukan. Polish Journal of Soil Science, 53(1), 81-95. https://doi. org/10.17951/pjss/2020.53.1.81

Irawan, A., Jufri, Y., \& Zuraida. (2016). Andisol chemical properties, growth and production of wheat (Triticum eastivum L.). Jurnal Kawista, 1(1), 1-9. Retrieved from http:// jurnal.unsyiah.ac.id/agrotek/article/view/3183

Isnaini, S. (2005). Soil ammonium and potassium contents and their uptake as well as yield of lowland rice as affected by tillage system and application of nitrogenand potassium fertilizers. Jurnal Ilmu-Ilmu Pertanian Indonesia, 7(1), 23-34. Retrieved from http://repository.unib.ac.id/148/

Kalu, S., Koirala, M., Khadka, U. R., \& Anup, 
K. C. (2015). Soil quality assessment for different land use in the panchase area of Western Nepal. International Journal of Environmental Protection, 5(1), 38-43. https://doi.org/10.5963/ijep0501006

Liu, Z., Zhou, W., Shen, J., Li, S., \& Ai, C. (2014). Soil quality assessment of yellow clayey paddy soils with different productivity. Biology and Fertility of Soils, 50, 537-548, https://doi.org/10.1007/s00374-013-0864-9

Ma, Y., Xu, J., Wei, Q., Yang, S., Liao, L., Chen, S., \& Liao, Q. (2017). Organic carbon content and its liable components in paddy soil under water-saving irrigation. Plant, Soil and Environment, 63(3), 125-130. https:// doi.org/10.17221/817/2016-PSE

Maharjan, B., Gauchan, D. P., \& Lamichanne, J. (2017). Soil quality and productivity in organic farming in context of Nepal: A Review. International Journal of Research, 4(8), 892-911. Retrieved from https:// journals.pen2print.org/index.php/ijr/article/vi ew/8347

Mujiyo, M., Sunarminto, B. H., Hanudin, E., \& Widada, J. (2015). Pertumbuhan dan hasil padi sawah organik dengan menggunakan pupuk kandang sapi dan azolla. Caraka Tani: Journal of Sustainable Agriculture, 30(2), 6975. https://doi.org/10.20961/carakatani.v30i2. 11892

Mujiyo, Rahayu, Ustiatik, R., \& Anggrahini, D. S. (2016). Mapping of soil degradation potency in paddy field Wonogiri, Indonesia. Sains Tanah - Journal of Soil Science and Agroclimatology, 13(1), 25-30. http://dx.doi. org/10.15608\%2Fstjssa.v13i1.481

Mukhopadhyay, S., Maiti, S. K., \& Masto, R. E. (2014). Development of mine soil quality index (MSQI) for evaluation of reclamation success: A chronosequence study. Ecological Engineering, 71, 10-20. https://doi.org/ 10.1016/j.ecoleng.2014.07.001

Nakajima, T., Lal, R., \& Jiang, S. (2015). Soil quality index of a crosby silt loam in central ohio. Soil and Tillage Research, 146(Part B), 323-328. https://doi.org/10.1016/j.still.2014. 10.001

Patti, P. S., Kaya, E., \& Silahooy, C. (2018). Analisis status nitrogen tanah dalam kaitannya dengan serapan $\mathrm{N}$ oleh tanaman padi sawah di Desa Waimital, Kecamatan Kairatu, Kabupaten Seram Bagian Barat. Agrologia, 2(1), 51-58. https://doi.org/10.30598/a.v2i1. 278

Priadi, D., Kuswara, T., \& Soetisna, U. (2017). Padi organik versus non organik: Studi fisiologi benih padi (Oryza sativa 1.) kultivar lokal rojolele. Jurnal Ilmu-Ilmu Pertanian Indonesia, 9(2), 130-138. https://doi.org/ 10.31186/jipi.9.2.130-138

Prihastuti, P. (2011). Struktur komunitas mikroba tanah dan implikasinya dalam mewujudkan sistem pertanian berkelanjutan. El-Hayah, 1(4), 174-181. https://doi.org/10.18860/elha. v1i4.1785

Rezaee, L., Moosavi, A. A., Davatgar, N., \& Sepaskhah, A. R. (2020). Soil quality indices of paddy soils in Guilan province of northern Iran: Spatial variability and their influential parameters. Ecological Indicators, 117 (March), 106566. https://doi.org/10.1016/j. ecolind.2020.106566

Sione, S. M. J., Wilson, M. G., Lado, M., \& González, A. P. (2017). Evaluation of soil degradation produced by rice crop systems in a Vertisol, using a soil quality index. Catena, 150, 79-86. https://doi.org/10.1016/j.catena. 2016.11.011

Soil Research Institute. (2009). Petunjuk teknis analisis kimia tanah, tanaman, air, dan pupuk (2nd ed). Bogor: Soil Research Institute. Retrieved from https://balittanah.litbang.perta nian.go.id/ind/dokumentasi/juknis/juknis_kim ia2.pdf

Sparling, G. P. (2020). Soil Quality: Indicators. In Managing Soils and Terrestrial Systems (2nd Edition, pp. 357-360). CRC Press. https://doi.org/10.1201/9780429346255-44

Supartha, I. N. Y., Wijana, G., \& Adnyana, G. M. (2012). Application of organic fertilizer type on rice crops organic agriculture systems. E-Jurnal Agroekoteknologi Tropika (Journal of Tropical Agroecotechnology), 1(2), 98-106. Retrieved from https://ojs.unud.ac.id/index. php/JAT/article/view/2178

Supriyadi, Mustikaningrum, I. A., Herawati, A., Purwanto, \& Sumani. (2018). Soil quality assessment in organic and non organic 
paddy fields in Susukan, Indonesia. Bulgarian Journal of Agricultural Science, 24(5), 777-784. Retrieved from https://www. agrojournal.org/24/05-07.pdf

Supriyadi, Purwanto, \& Pradika, V. (2015). To study the effect of soil macrofauna on soil quality in Keduang Sub. International Journal of Agriculture, Forestry and Plantation, 1(1), 78-84. Retrieved from https://ijafp.com/wpcontent/uploads/2015/10/AG-58.pdf

Supriyadi, Purwanto, Sarijan, A., Mekiuw, Y., Ustiatik, R., \& Prahesti, R. R. (2017). The assessment of soil quality at paddy fields in Merauke, Indonesia. Bulgarian Journal of Agricultural Science, 23(3), 443-448. Retrieved from https://www. agrojournal.org/23/03-13.pdf

Supriyadi, Dewi, W. S., Nugrahani, D., Rahmah, A. A., Haryuni, \& Sumani. (2019). The assessment of soil quality index for paddy fields with indicator biology in Jatipurno Districts, Wonogiri. Modern Applied Science, 14(1), 20-33. https://doi.org/10.5539/mas.v14n1p20

Surekha, K., Rao, K.V., Shobha Rani, N., Latha, P. C., \& Kumar, R. M. (2013). Evaluation of organic and conventional rice production systems for their productivity, profitability, grain quality and soil health. Agrotechnology,
(S11), 006. https://doi.org/10.4172/2168-988 1.s11-006

Susilawati, Budhisurya, E., Anggono, R. C. W., \& Simanjuntak, B. H. (2013). Soil fertility analysis with soil microorganism indicator on various systems of land use at Dieng Plate. Agric, 25(1), 64-72. https://doi.org/10.24246/ agric.2013.v25.i1.p64-72

Tangketasik, A., Wikarniti, N. M., Soniari, N. N., \& Narka, I. W. (2014). Kadar bahan organik tanah pada tanah sawah dan tegalan di Bali serta hubungannya dengan tekstur tanah. Agrotrop: Journal on Agriculture Science, 2(2), 101-107. Retrieved from https://ojs. unud.ac.id/index.php/agrotrop/article/view/78 20

Thomas, G. V., Shantaram, M. V., \& Saraswathy, N. (1985). Occurrence and activity of phosphate-solubilizing fungi from coconut plantation soils. Plant and Soil, 87(3), 357364. https://doi.org/10.1007/BF02181903

Van Leeuwen, J. P., Lehtinen, T., Lair, G. J., Bloem, J., Hemerik, L., Ragnarsdóttir, K. V., Gísladóttir, G., Newton, J. S., \& De Ruiter, P. C. (2015). An ecosystem approach to assess soil quality in organically and conventionally managed farms in Iceland and Austria. Soil, 1(1), 83-101. https://doi.org/10.5194/soil-183-2015 